\title{
Irish Captives in the British and Spanish Mediterranean 158o-176o
}

\author{
Thomas O'Connor
}

The early modern Irish were agents in numerous international networks, usually riding on the coattails of English, Dutch, French, Spanish and Portuguese contemporaries.* It has been usual to examine these Irish agents within, rather than across, the different imperial systems that alternately sheltered, shunned and shared them. ${ }^{1}$ However, like other mobile minorities at the time, the Irish operated opportunistically across, as well as within, imperial systems. Although their choices were more often than not buffeted by the winds of necessity and circumstance, the Irish, when occasion allowed, could be strategic in their choice of host networks, particularly during times of war, as in the 159os, 1640s, 169os and throughout the eighteenth century. It was in conflictual situations that the Irish most effectively straddled colonial boundaries, as soldiers, clerics and merchants. This permitted them a significant role in enabling connectivities between Britain and Iberia in the early modern period.

It was within the interlocking English and Spanish spheres in particular, that the Irish learned to play on the ambiguities of their identity as (generally) Catholic subjects of a Protestant monarch. This was the case notably on the shifting frontiers between Central and North America, where Irish military, clergy and traders moved between English and Spanish zones of influence. ${ }^{2}$ They displayed similar talents on the Canary Islands, notably in the commercial

* Abbreviations: Ags = Valladolid, Archivo General de Simancas; AHN = Madrid, Archivo Histórico Nacional; ANTT = Lisbon, Arquivo Nacional do Torre do Tombo; APF = Rome, Archivio Storico di Propaganda Fide; TNA = Kew, The National Archives; Tso = Lisbon, Arquivo Nacional do Torre do Tombo, Tribunal do Santo Oficio.

1 For overviews of recent work on the Irish overseas, see O'Reilly W., "Ireland in the Atlantic World: Migration and Cultural Transfer", in Ohlmeyer J. (ed.), The Cambridge History of Ireland, vol. 2: 1550-1730 (Cambridge: 2018) 385-408; Chambers L., "The Irish in Europe in the Eighteenth Century 1691-1815", in Kelly J. (ed.), The Cambridge History of Ireland, vol. 3: 1730-1880 (Cambridge: 2018) 569-592.

2 O'Connor T., "Irish Collegians in Spanish Service (156o-180o)", in Chambers L. - O'Connor T. (eds.), Forming Catholic Communities. Irish, Scots and English College Networks in Europe, 1569-1918 (Leiden: 2017) 15-38. 
sphere. ${ }^{3}$ Less well known are their trans-imperial activities in another zone of English-Spanish overlap, the Western Mediterranean. ${ }^{4}$ As will be seen, these activities were largely mediated through the military, commercial and slaving networks of Britain, Spain and the North African Moors. ${ }^{5}$ As a result, Hiberno-Maghreb contacts in the period tended to be confrontational, whether the Irish were on British military campaigns in North Africa, ${ }^{6}$ members of Spanish naval missions in the Mediterranean, ${ }^{7}$ trading on the corsairridden high seas ${ }^{8}$ or resisting Moorish land raids and enslavement at home. ${ }^{9}$

Such encounters could and did lead to the Moorish imprisonment of Irish subjects, some of whom had already been uprooted from their traditional lands and occupations by the progress of the English conquest in Ireland. ${ }^{10}$ Their captivity and enslavement in North Africa entailed a further dramatic change in their social status and, in the case of renegades, of religion too. Returning renegades of all nationalities were required to undergo ritual reintegration into Christendom, ${ }^{11}$ a process supervised, in the Spanish sphere, by the Inquisition. This processing generated a considerable paper record, much of which has survived. Bartolomé and Lucile Bennassar analysed about 1,500 of these reconciliation accounts, estimating that, for the period $155^{\circ}-$ 1700 , they represent about one half of one per cent of the total number of

On the activities of the Walsh and Cologan families in Tenerife, see Guimerá Ravina A., Burguesía extranjera y comercio atlántico: la empresa comercial irlandesa en Canarias (1703-71) (Tenerife: 1985).

4 See O'Connor T., Irish Voices from the Spanish Inquisition: Migrants, Converts and Brokers in Early Modern Iberia (London: 2016) 83-86.

5 The Moors were North African peoples of Muslim religion, one portion of whom, prior to the Reconquista, was firmly established in Iberia.

6 There is no comprehensive treatment but see Bejjit K., English Colonial Texts on Tangier 1661-1684: Imperialism and the Politics of Resistance (London: 2015) passim; Barrio Gozalo M., "Los cautivos españoles en Argel durante el siglo illustrado", Cuadernos Dieciochistas 2 (2003) 135-174.

7 See, for example, AGS GA Leg 883 (12 Jan. 1622).

8 For example, the incident report in AHN INQ Lib 1021, fols. 271r-281r. On Gráinne Ní Máille's (c.1530-c.16o3) alleged encounters with Turkish corsairs in 1567, see Druett J., She Captains: Heroines and Hellions of the Sea (New York: 2000) 58; Chambers A., The Life and Times of Grace O'Malley (Dublin: 1979).

9 Murray T.D., "From Baltimore to Barbary: The 1631 Sack of Baltimore", History Ireland 14, 4 (2006) 14-18; Barnby H., "The Sack of Baltimore", Journal of the Cork Historical and Archaeological Society 74 (1969) 101-129. On the sale of these Irish slaves in Algiers, see Pierre D., Histoire de la Barbarie et de ses Corsaires [...] divisée en dix livres (Paris, Pierre Rocolet: 1637) especially vol. 2, $178 \mathrm{ff}$ and vol. 3, 277ff.

10 For a general account, see Davis R.C., Christian Slaves, Muslim Masters: White Slavery in the Mediterranean, the Barbary Coast and Italy (1500-1800) (London: 2003). Ibidem 19, 184. 
Christians imprisoned by the Moors. ${ }^{12}$ These included a handful of Irish cases. Supplementing the Inquisition files are the Spanish and Portuguese state records of ransomed Christian slaves. In the seventeenth century, Spanish state ransoming was largely in the hands of the redemptive orders, the Trinitarians and Mercederians, who worked closely with the state. ${ }^{13}$ Between them, church and state archives in Spain contain references to several dozen Irish captives. ${ }^{14}$ In Protestant England and Ireland, both church and state organised ransoming schemes..$^{15}$ The surviving documentation, notably the English state papers, contains records pertaining to over one hundred enslaved Irish. ${ }^{16}$ Overall, these English, Spanish and Portuguese records permit a partial reconstruction of how Irish captives crisscrossed British and Spanish spheres of influence. Their experience offers an insight into the complexity of British-Hispanic relations in the Western Mediterranean in the early modern period.

It is tempting to view these Hiberno-Maghrebin encounters predominantly through the romantic but distorting lens of piracy, slavery and apostacy. They are, in fact, more appropriately located in the rapidly changing geo-political and commercial circumstances that marked Irish involvement in expanding British and Spanish activity in the Maghreb. ${ }^{17}$ Despite their rivalries, Britain and Spain shared the same mercantilist outlook. Protecting their commercial interests in the Mediterranean required naval backup, bringing ever larger numbers of Europeans into contact with North African populations. This explains, for instance, the heavy English military investment in the city of Tangier, which had come into temporary English possession (1661-1684), as part of Catherine of Braganza's dowry. ${ }^{18}$ With the seizure of Gibraltar (1704) and Minorca (1708), the British presence in the Mediterranean was copper-fastened. British forces in the Mediterranean, notably in Tangier, included several hundred Irish

12 Bennassar B., Les chrétiens d'Allah. L'histoire extraordinaire des renégats XVI-XVII siècles (Paris: 1989) 174; Davis, Christian Slaves 3-26.

13 Martínez Torres A.J., Prisioneros de los infieles: vida y rescate de los cautivos cristianos en el Mediterráneo musulmán (siglos XVI-XVII) (Barcelona: 2004).

14 O'Connor, Irish Voices, passim.

15 See the transcript of the Laudian rite for returned renegades (1637) in Vitkus D.J. (ed.), Piracy, Slavery and Redemption: Barbary Captivity Narratives from Early Modern England (New York: 2001) 361-366.

16 Matar N., British Captives from the Mediterranean to the Atlantic, 1563-1760 (Leiden: 2014).

17 For more recent work, see Davis, Christian Slaves; Bennassar, Les chrétiens; Heers J., Les Barbaresques (Paris: 2008). For the later period see Panzac D. Les Corsaires barbaresques: la fin d'une épopée, 1800-1820 (Paris: 1999).

18 For a contemporary account see [Philips George], The present state of Tangier: in a letter to his Grace the Lord Chancellor of Ireland and one of the Lords Justices there to which is added The Present State of Algiers (London: Henry Herringman, 1676). 
subjects. The Spanish, of course, had preceded the English in North Africa by over a hundred years and, during the Reconquista, seized several territories there. By the end of the seventeenth century, Spanish footholds in Africa included Melilla, Alhucemas, Peñon de Vélez de la Gomera, Ceuta, Oran and Mazalquivir. ${ }^{19}$ Maintaining these North African enclaves required significant garrisoning and provisioning capacity, for part of which the Spanish, like the English, relied on Irish military migrants and commercial networks. By the eighteenth century, there were three Irish regiments in Spanish Bourbon service, all intermittently stationed in North Africa. ${ }^{20}$

\section{Irish Captives in the Maghreb}

The mobility of sections of the Irish population from the 159os, coupled with their presence in the Spanish and British military establishments, coincided, in the Mediterranean and the Atlantic, with a period of increased corsair activity. ${ }^{21}$ Consequently, from the 159 os, more and more Irish ended up, temporarily or permanently, in Moorish captivity. For the Moors, Christian captives, like the Irish, were valuable for their skills and labour but their captors valued them most for ransom, particularly if they were of rank or in holy orders. For instance, the Irish cleric, Cornelio Naughten, who was chaplain to the Thomas Stukley-led force commandeered by the Portuguese King Sebastião in 1578, was taken prisoner by the Moors and enslaved in Algiers. In 1591, his master was paid off with a Spanish ransom. ${ }^{22}$ Other ransomed Irish clerics included the Lisbon-based Irish Dominican, Andrew O'Hurley, redeemed in $1635 .{ }^{23} \mathrm{After}$ his capture in 1615, another Irish Dominican, Anthony Lynch spent eight years in captivity prior to ransoming. ${ }^{24} \mathrm{Had}$ it not been for their clerical status these individuals would have languished longer, if not permanently, in captivity.

19 The last two were lost in 1708 but retaken in $173^{2}$ as the Spanish Bourbons decided to flex their naval muscle in response to growing British influence in the area.

20 Murphy D., The Irish Brigades 1685-2006 (Dublin: 2007) 41-56.

21 For periodisation, see Martínez Torres, Prisioneros de los infieles 151-54.

22 García Hernán E., La cuestión irlandesa en la política internacional de Felipe II (Ph.D. dissertation, Universidad Complutense, Madrid: 1999) 214-215.

23 APF, SOCG, 103, fols. 122-139; 104, fols. 141-144; 135, fol. 529, cited in Fenning H., "Irish Dominicans at Lisbon before 1700: A Biographical Register", Collectanea Hibernica 42 (2000) 27-65, here 51. He has been previously active in Pamplona (1622) and elsewhere in Spain.

24 Fenning H., "Irish Material in the Registers of the Dominican Masters General: 1390-1649", Archivum Fratrum Praedicatorum 39 (1969) 249-336, here 281. He had entered the Irish College in Lisbon as a late vocation, later moving to Salamanca and, in 1605, joined the 
The majority of captives were not so fortunate. It has been estimated that, on average, less than three per cent of all Moorish captives in any one year, were ransomed. ${ }^{25}$ Unless a captive was of high birth, well up the ecclesiastical hierarchy or a member of a religious order, prospects were grim. True, two religious orders, the Trinitarians, ${ }^{26}$ active mostly in Algiers and Tunis, and the Mercederians in Morocco, worked to raise ransom funds in Europe. ${ }^{27}$ In the early seventeenth century, the Irish, as foreigners, were ineligible for relief. ${ }^{28}$ However, the growing importance of Irish military in Spanish forces, the increasing numbers falling into captivity and the persistence of Irish petitioners at court persuaded the king, in the 1620 , to admit the Irish to Spanish ransoming schemes. ${ }^{29}$

This improved the ransoming prospects, however, of only a very small number. For long-term and permanent captives, their treatment depended on their usefulness to their owners. If slaves were educated, they were often put into domestic service and lived in their masters' households; skilled workers like shipwrights were especially valued by the Moors and often sent to local arsenals. ${ }^{30}$ The owners of skilled slaves were unlikely to accept ransoms, unless they were sufficiently attractive. Unskilled, run of the mill slaves of low social status, were destined for menial tasks like agricultural labouring, water carrying, quarrying and, worst of all, the galleys. They were permanently housed in the infamous bagnios, released every morning to take up their work and

Dominicans. He submitted two memorials describing his captivity and providing strategic information about his captors to the Spanish king. See AGS Estado Leg $275^{2}$.

25 Davis, Christian Slaves 21.

26 The Trinitarians had had a house in Ireland, in Adare, suppressed, in the sixteenth century. See Giblin C., "Documents of the Irish Trinitarians, 1621-71", Collectanea Hibernica 27/28 (1986) 11-43. Later attempts to refound the Irish Trinitarian were supported by claims that they would contribute to the care of Irish captives and other subjects of the English king held in the Maghreb. See Petition of Cardinal Prefect of Propaganda on behalf of Irish Trinitarians (APF, SOCG, 4O2, fol. 456r (1641)), cited in Giblin, "Documents" 28.

27 The best account is Martínez Torres, Prisioneros de los infieles. See also Davis, Christian Slaves 149 .

28 Records of 10,000 redemptions, carried out by these two religious orders between 1575 and 1769 exist. See Martínez Torres, Prisioneros de los infieles, passim and Friedman, "North African Piracy" 5.

29 In their petitions, the Irish argued that their common Milesian ancestry with the Spanish, entitled them to equal treatment. See AGS GA Leg 954, Council of War, 18 Aug. 1627.

30 In the early eighteenth century, for instance, an Irishman called Carr acted as founder for the Moroccan sultan, Ismael Ibn Sharif (d. 1727). See Braithwaite J., The History of the revolutions in the Empire of Morocco upon the death of the late Emperor Muley Ishmael (London, J. Darby and T. Browne: 1729) 180. 
returning for lockdown in the evening. Most of these died in captivity and have left no archival record.

There were some concessions to captives. For instance, Catholic clerics were sometimes allowed to minister to their fellow slaves. ${ }^{31}$ Following his capture in the late 162os, the Dominican, Raymond O'Hehir provided pastoral services to other Christian captives. ${ }^{32}$ Moorish indulgence in this regard extended to Protestants too. In 1641, Devereux Spratt, an Anglican minister in Munster was captured with 120 others, off the Irish coast. He was taken to Algiers, acquired a tolerant master who allowed him to minister to other Anglicans in the city. ${ }^{33}$ Over time, certain informal bagnio ministries developed into organised chaplaincies, ${ }^{34}$ with other slaves paying for the serving priest to be relieved of slave service in order to administer the sacraments. From the $1620 \mathrm{~s}$, missionaries were sent by Roman Congregation of Propaganda fide to serve bagnio slave groups. ${ }^{35}$

In general, Christian captives were not required to convert to Islam although certain owners might insist that they did. In 1677, the Irish Lord Lieutenant was informed that 'if a slave turns runnegado, it is at the pleasure of his patron to have him written in the pay for he continues still a slave, unless his patron give him his liberty' ${ }^{36}$ The evidence tends to bear this out. An Irish student for the Dominican order, taken on the high seas on his way to Spain in the late seventeenth century, was enslaved and was reportedly tempted to convert by his master's offer of his own daughter's hand in marriage. ${ }^{37} \mathrm{He}$ appears to have demurred. For the few Irish female slaves for whom we have records, conversion, if ordered by their master, could not be resisted. In the 1720s, when he took an Irishwoman named Mrs Shaw as one of his wives, Ismael Ibn Sharif insisted that she convert. ${ }^{38}$ However, in general, conversion seems to have reduced the worth of the slave as chattel. Moorish captors were more concerned to convert

$31 \quad$ Davis, Christian Slaves 88.

32 Flynn T.S., The Irish Dominicans 1536-1641 (Dublin: 1993) 115; Fenning, "Irish Dominicans at Lisbon before 1700". See, for instance, Papal collector to Propaganda, APF, SOCG, 104, fols. 131-132 (ibidem, 27).

33 Colley L., Captives: Britain, Empire and the World 1600-1850 (London: 2002) 106.

34 Martínez Torres Prisioneros 68-74; [Philips] The present state of Tangier 92-93.

35 Filesi T., "L'attenzione della Sacra Congregazione per l'Africa settentrional", in Metzler J. (ed.), Sacrae Congregationis de Propaganda Fide memoria rerum: 350 anni al servizio delle missioni, vol. 1.2: 1622-1972 (Rome: 1972) 381-393.

36 [Philips] The present state of Tangier 100-101.

37 O'Heyne John, The Irish Dominicans of the Seventeenth Century (Louvain: 1706; reprint Dundalk: 1902) 76 .

38 Braithwaite, The History of the revolutions 191. 
their property into hard currency than into believers. ${ }^{39}$ It has been estimated that no more than perhaps four per cent of the total number captured 'took the turban' and turned renegade. ${ }^{40}$

In this context it needs to be borne in mind that at least some renegades went to the Maghreb voluntarily, in flight, perhaps, from the law or in search of a new life. ${ }^{41}$ In 1735 , Richard Murphy of Galway, in a fit of pique against the English consul in Tunis, took the turban. ${ }^{42}$ In general, European authorities were loath to admit that any Christian could 'turn Turk' voluntarily. ${ }^{43}$ However, in 1636, Sir Henry Blount (1602-1682) lamented, 'Seeing how many daily goe from us to them and how few of theirs to us; it appears of what consequence the prosperity of a cause is to draw men unto it'.44 Later, in the eighteenth century, the English emissary to Morocco, John Russell, noted how many Irish renegades served the Moroccan sultan Ahmed ed-Dehebi (d. 1729), acting as mariners, interpreters and soldiers. ${ }^{45}$ At least some of these voluntarily chose life in Africa and Muslim observance. ${ }^{46}$ This was perhaps most often the case with captives of military origin, for whom desertion was one way of escaping army discipline and the dangers of war.

\section{$2 \quad$ Irish Military and Naval Captives}

Indeed, the earliest cases of Irish captives processed by the Spanish Inquisition concerned skilled military or naval personnel. Typical in this regard was Irish naval gunner, Nicholas Vualles (possibly 'Wallace'), processed by the Lisbon Inquisition in $1585 .{ }^{47}$ In 1618 , Dominic Rice, another Irish gunner, appeared before the Lisbon Inquisition charged with Islamism. ${ }^{48}$ Later, in 1631, the Inquisition expedited the processing of James Treves because the defendant was already destined for service in the Spanish navy. ${ }^{49}$ Their testimonies do not make clear why they converted to Islam and it cannot always be assumed, as they generally claimed themselves, that their apostacy was forced.

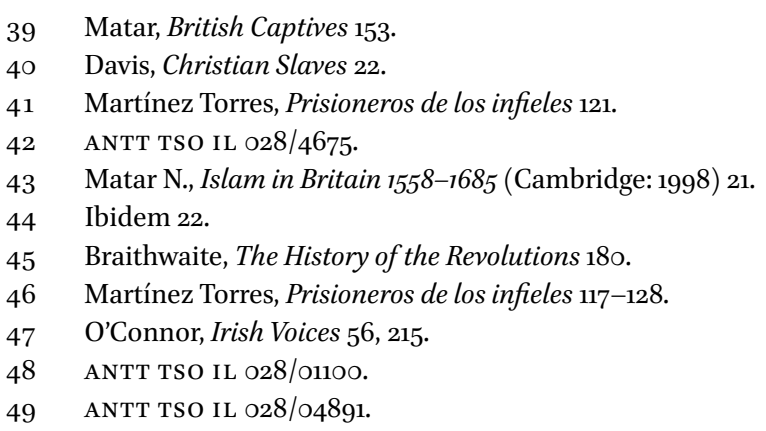


In the early seventeenth century, the number of Irish entering Spanish service rose sharply. Many of these had been associated, in the 1590s and 16oos, with the O'Neill-led rebellion against Elizabeth I and, following their defeat by the English, were absorbed into Spanish forces, largely in the Netherlands. ${ }^{50}$ Smaller numbers, drawn mainly from Munster and Connaught maritime families, joined the Spanish navy, bringing them to the Mediterranean zone and contact with the Moors. ${ }^{51}$ In the first half of the seventeenth century, at least two vessels with Irish companies fell prey to Maghrebin corsairs. The first, under Captain Arthur O'Morachen, were aboard the Imperial when it was taken by North African corsairs off the coast of Cartagena in 1620. Only nine company members survived the initial assault and they were taken to Algiers as prisoners, where they appear to have been sold to a Greek renegade and held for ransom..$^{52}$ 'Morachen, who repeatedly petitioned the Spanish for ransom, was later sold to an Ottoman officer, who, because he was organizing a prisoner exchange with the Spanish, may have calculated that the Irish captain would be a useful pawn. At the conclusion of these negotiations, in 1622, O'Morachen was released at Oran while his companions remained incarcerated.

They were soon joined by another group of Irish military captives. In 1622, a second Irish company, under Cornelius O'Driscoll, was engaged against the Dutch, abroad the Nuestra Señora del Rosario. Temporarily separated from the main fleet, they were intercepted by Moorish pirates. All the officers were killed and the surviving crew, on surrender, were taken to Algiers. ${ }^{53}$ This group of detainees, along with the still-imprisoned crew of the Imperial were the object of representations by certain Irish petitioners to various Spanish Councils. A prisoner exchange was attempted but the officer accompanying the Moorish prisoner to Africa, John Fleming, was himself captured and held for ransom.

Over the following years, negotiations for prisoner exchange continued but the Spanish authorities were reluctant to pay up. Some Irish captives attempted to apply their arrears for military service to their ransom, but this was a complex process, requiring influence at court. Charles McCarthy, for instance, repeatedly petitioned the court on this count but eventually died in captivity in 1636 . Some of the Irish appear to have benefited, eventually, from ransoms

50 See de Mesa E., The Irish in the Spanish Armies in the Seventeenth Century (Woodbridge: 2014); O'Scea C., Surviving Kinsale: Irish Emigration and Identity Formation in Early Modern Spain, 1601-40 (Manchester: 2015). The author acknowledges the generosity of Dr Eduardo de Mesa in sharing unpublished information on the Irish in Spanish naval service.

$5^{2} \quad$ AGS GA Leg 883 (12 Jan. 1622).

53 Ibidem. 
organized by the religious orders. ${ }^{54}$ Other prisoners, like Florence O'Driscoll were redeemed by Irish merchants. For his part, Florence McCarthy was released in 1624 and some others, including Phelim Kavanagh in 1626, managed to escape. Thaddeus O'Driscoll was not freed until 1630, following drawn-out exchange negotiations with the Moors. But as late as 1641 one of the prisoners, the unfortunate Cormac Phelan, from the Rosario was still enslaved. ${ }^{55}$

Throughout the 1640s, Irish military captives in Spanish service continued to appear before the Inquisition and also feature in state archives. In 1645, for instance, James Morlim, sailor and gunner, appeared before the Coimbra tribunal charged with conversion to Islam. ${ }^{56}$ However, from mid-century, peripatetic Irish soldiers were less well viewed in Spain, as they gradually shifted their loyalty from the Spanish Habsburgs to the French Bourbons. ${ }^{57}$ It was at this stage too that they became more visibly active in British overseas service and, between 1661 and 1684, about a thousand Irish soldiers served in the British garrison stationed in Tangier. ${ }^{58}$

The vulnerability of the Tangier garrison greatly increased the risk of capture and enslavement. This was largely because the garrison was provisioned from abroad. Supply lines were unreliable, so the men were obliged to forage locally. Their sallies were often intercepted by the Moors, resulting in heavy British casualties and many hostages. ${ }^{59}$ The plight of the garrison did not improve under its third Irish governor, Thomas Dongan $(1634-1715) \cdot{ }^{60}$ In fact, Moorish pressure on the garrison increased in the late 1670s, necessitating the deployment of fresh troops from Britain and Ireland. ${ }^{61}$ Local insecurity, the

54 Irish petitioners in Spain argued that because of their common Milesian ancestry with the Spanish, the Irish ought to be treated equally. See AGS GA Leg 954 (18 Aug. 1627).

55 AGS GA Leg 1399 (28 June 1641; 11 Sept. 1641).

56 ANTT TSO IC 025/06752.

57 Stradling R.A., The Spanish Monarchy and Irish Mercenaries (Dublin: 1994) 154.

$5^{8}$ This followed Tangier's transfer from Portuguese to British authority as part of Catherine of Braganza's dowry. On Tangier, see Routh E.M.G., Tangier: England's Lost Atlantic Outpost 1661-1684 (London: 1912); Childs J., The Army of Charles II (London: 2013) 115-151; General Percy Kirke and the Later Stuart Army (London: 2014) 31-66.

59 [Philips], The present state of Tangier.

6o He was later 2nd Earl of Limerick and governor of New York.

61 The Tangier establishment was charged to the Irish Exchequer until 1684, when it was abandoned, Tangiers cost about $£_{3} \mathrm{O}, 000$ annually. See Moody T.W. - Martin F.X. Byrne F.J. (eds.), A New History of Ireland, vol. 3: Early Modern Ireland 1534-1691 (Oxford: 1976) 440-441. One of the few permanent Irish legacies in Tangier is the ruined 'Irish Battery' (Cubelo do obispo) in the ancient city walls. See Carabelli R., "The 'Oldest Modern' Colonisation in Africa", in Nunes Silva C. (ed.), Urban Planning in North Africa (London: 2016) 31-42; and "The 'Oldest Modern' Colonisation in Africa”, in Nunes Silva C. (ed.), Urban Planning in North Africa (London: 2016) 31-42. 
expense of supporting the garrison and Protestant suspicions concerning the eventual destination of the Catholic portion of the Tangier garrison led to the port's abandonment in 1684. At this time several soldiers were ransomed from Moorish bagnios but it is unclear if many of these were Irish. In general, the Stuarts had limited interest in ransoming any of their subjects and were particularly neglectful of the Irish, who rarely appear in the records. ${ }^{62}$ Of the captives taken in Baltimore in 1631, for instance, no more than two of the women are known to have been freed and this in spite of the fact that many of the captives were recently arrived English settlers in the Baltimore area. ${ }^{63}$ In fact, it was only under the Commonwealth that the Irish won entitlement to the benefits of treaties negotiated between London and Algiers. ${ }^{64}$ This situation proved temporary. In 1670, when Charles II raised ransom money by letters patent, he was careful that only money raised in Ireland be applied to Irish captives. ${ }^{65}$ Complicating the matter still further was the fact that not all the Irish captives in the Maghreb in the seventeenth century were enslaved sailors or victims of Moorish land raids in Ireland. Some, captured on their way to indentured service in the Americas, were already unfree when intercepted by corsair missions. Neither the Stuarts nor the Commonwealth appear to have had much interest in ransoming them. This must have dismayed their Moorish captors whose principal hope of profit lay in the ransoming of their recently acquired human property. 66

Domestic wars in Britain absorbed Irish mercenaries at the end of the 168os, but with the defeat of James II in 1691, their numbers surged, first in French and, following the wars of the Spanish Succession, in Spanish Bourbon service too. At this time, three Irish regiments were established in Spain (Irlanda, Hibernia and Ultonia), and, because all of these saw African service, some Irish soldiers inevitably fell into Moorish custody. In 1724, a 2nd lieutenant, one Matthew Molony, appeared before the Lisbon Inquisition to purge his Islamism. ${ }^{67}$ Having previously served in France, he had been in Spanish service in Melilla. He claimed to have fallen into Moorish hands while crossing Muslim territory, having assumed that, as an Irish subject and hence of a kingdom not at war

62 MacLean G. - Matar N., Britain and the Islamic world 1558-1713 (Oxford: 2011) 129.

63 In 1647 two women from this group were ransomed. See MacLean - Matar, Britain and the Islamic World 129. One of the female captives, called O'Driscoll, allegedly stabbed her Moorish master in the middle of his seraglio. See White-Spunner B., Horse Guards (London: 2006) 74. Earlier, from 1637, there is a record of the ransom of two Irish women: Grace Marten from Bantry and Elizabeth Renordan from Kinsale. They may have been part of the Baltimore group. See ibidem. 13 .

64 Matar, British Captives 106.

65 Ibidem 155.

66 Ibidem 111.

$67 \quad$ ANTT TSO IC 028/13113. 
with the Moors, he had free passage. He was mistaken: captured at Meknes, he was held for ten years prior to his escape. The majority of the Irish hostages in this period were members of the Spanish garrison in Oran. ${ }^{68}$ The Algerian port had been a Spanish enclave from 1509 but fell to the local Moors in 1708. In 1732, the Spanish decided to attempt to retake it, in part to counter English influence in the zone. ${ }^{69}$ Among the thousands of Spanish soldiers on this mission were Irish battalions under General William Lacy (1682-1753). One of the Irish officers, Arthur Magennis, was captured and held in Algiers for five years, ${ }^{70}$ before ransoming in $1737 .^{71}$ Thereafter, the Ultonia regiment was stationed in Oran between $1740-1748$ and later from $1786-1787 .^{72}$ It seems to have been a tough station, as over $45^{\circ}$ regimental members deserted during that period. ${ }^{73}$ How many of these ended up in Moorish custody is unclear.

The fact that they were in Spanish service did not prevent certain of these Irish soldiers, once in Moorish captivity, requesting British assistance. This provides a revealing example of the trans-imperial agency of the Catholic Irish. In this case, however, the evidence suggests that they received scant sympathy from either their Hanoverian or their Bourbon overlords. Apart from their Catholicism, their Jacobitism, putative or otherwise, disqualified them from British succor. British authorities were especially piqued by the participation of the Irish regiments in the Anglo-Spanish War (1727-1729), notably at the siege of Gibraltar and consequently suppliant Irish captives got short shrift. ${ }^{74}$ Thus, when Captain Thomas Barry led an escape bid from the Algiers bagnio in 1737 and succeeded in taking to sea in a small boat, he was not only repelled from a visiting English vessel but the ship's captain returned him to the Algerians. ${ }^{75}$ A similar cold shoulder awaited Irish officers in Algerian custody in 1748. They

68 Alonso Acero B., Orán-Mazalquivir 1589-1639: una sociedad española en la frontera de Berbería (Madrid: 200o).

69 Fé Cantó L.F., "El desembarco en Orán en 1732. Aproximación analítica a una operación compleja", Revista Universitaria de Historia Militar 5, 10 (2016) 89-110.

$70 \quad$ Kerney Walsh M., "The Irish College Madrid", Seanchas Ardmhacha:Journal of the Armagh Diocesan Historical Society 15, 2 (1993) 39-50, here 47, citing AGS GM Leg 2866; AGS Secretaría de Hacienda Leg 966; AHN Santiago Leg 5974.

71 He was later ordained priest, becoming rector of the Irish college in Madrid in about 1751. According to some sources, it was while imprisoned that he made a promise to enter religious life and, on release, reportedly took vows as a Trinitarian friar (Archivo Monasterio de las Descalzas Reales, 15, 27, fols. 1r-4v (Madrid, 1769)).

72 Mous L., Estudio del manuscrito árabe de Mustafá Ibn Abd Allāh al Dahāwi sobre la liberación de Orán en el siglo XVIII (Ph.D. dissertation: University of Oran: 2013) 73.

73 Ibidem 73 .

74 Murphy D., The Irish Brigades 1685-2006 (Dublin: 2007) 45.

75 Tomás Barry to Duke of Montemar, Algiers, 12 Dec. 1737 (AGS GM Leg 1531) cited in Barrio Gozalo M., "Los cautivos españoles en Argel durante el siglo ilustrado", Cuadernos Dieciochistas 2 (2003) 135-174, here 168, n. 117. 
included Nicholas O'Reilly, a member of the Hibernia regiment ${ }^{76}$ who was to spend over three years in captivity. ${ }^{77}$ The plight of the Spanish-Irish was reported to London but English authorities disclaimed all responsibility for these Jacobites, 'inflamed' as they saw them 'with the quixotism they have learned in Spain: ${ }^{78}$ It would seem from this passage that part of the British problem with the Irish was the extent to which they allegedly resembled the Spanish.

\section{3}

\section{Civilian Captives}

Although Irish captives were usually military men, some of the best documented cases recorded by the Inquisition concerned Irish civilian renegades. In 1619, for instance, Michael Hor [Hoare] presented before the Lisbon tribunal, charged with Islamism. ${ }^{79}$ His appearance was the result of an inquisitorial visitation to the island of Terceira in the Azores. Civilian Irish subjects who appear in the Iberian inquisitorial records were generally captured on trading or fishing trips to the Spanish coast. In 1626 David Gaudid (Wadding), a twenty-year-old Wexford-born sailor, processed by the Lisbon Inquisition, ${ }^{80}$ recounted how four years previously he had been aboard a vessel out of the port of Wexford, bound for Calais with a cargo of salt. Having disembarked there, he joined another crew bound for the sardine fisheries off the Portuguese coast. Shortly after arriving there, their vessel was taken by North African corsairs and brought to Salé. A similar fate befell James Treves, a merchant's son from Tredart (Tarbert?). In 1631, while returning with his uncle from a trading trip to Bilbao, their vessel was captured and he was taken to Salé as hostage.

Captives such as Treves and Wadding could expect to be moved around following capture. Wadding, it appears, was initially sold to a Moor name Mustafat. Capitalizing on his maritime experience and calculating, no doubt, that his chances of regaining his freedom would be enhanced if he secured a seafaring position, Wadding gained his master's confidence and was placed

76 AGS GM Leg 2592, C IV, fol. 20, cited in Recio Morales Ó., "Una aproximación al modelo del oficial extranjero en el ejército borbónico: la etapa de formación del teniente General Alejandro O'Reilly (1723-1794)", Cuadernos dieciochistas 12 (2011) 171-195, here 187, n. 6 o. He had two other brothers in Hibernia, Domingo and the more famous Alejandro (17231794). The latter led a famously disastrous Spanish mission against Algiers in 1775 . See Augustin Guimerá A., "Historia de una incompetencia: el desembarco de Argel, 1775", Revista Universitaria de Historia Militar 5, 10 (2015) 135-155.

78 Matar, British Captives 150, citing TNA SP 71/8/335-337.

79 ANTT TSO IL $028 / 12428$, fols. $1-22$.

8o $\quad$ ANTT TSO IL O28/o5626. 
in a corsair crew. For the following four years they plied the Mediterranean and the Atlantic. No doubt because he lacked Wadding's maritime experience, Treves' movements, were more landbound. After a month in captivity he was sold in a market near Tetouan. Seven years later he was sold on to an 'alfaate andalus' who had him transported back to Salé and thence to Fez. He was later sold on to a Moor called Jozejo, in Salé and taken to Algiers. In 1636, another Irish mariner, Peter Hall, reported to the Barcelona tribunal that he had been captured in the English Channel en route from Ireland to France and was taken to Algiers where he was sold to a Moorish soldier. He converted, was given the name Assan and subsequently participated in a number of missions against Christian shipping, under a renegade English captain called Marri. ${ }^{81}$

In contrast to most captives, skilled prisoners like these seem to have been pressurized to convert, probably because their Moorish masters counted to holding on to them permanently. At least that is what they told the Inquisition. Once before the inquisitors, renegades generally explained their apostacy as strategic, committed in order to avoid punishment or to enhance escape opportunities. In his account, Hall claimed that he had been forcibly circumcised. Wadding, for his part, was more nuanced. He said he was pressurized to convert with a mixture of inducements and threats. Only in extremis did he acquiesce to circumcision and don Moorish garb. Treves' account was not dissimilar. After some time in captivity he was dressed as a Moor and given a Moorish name. His circumcision, he claimed, required the assistance of no fewer than half a dozen Moors. His only reason for taking the turban, he recounted, was to have greater liberty to procure his eventual freedom.

If Wadding calculated that conversion and high seas servitude might provide an escape opportunity, he was right. On one of his corsair missions in 1626, the Moorish crew, on breaking the Ramadan fast, became inebriated. The apparently abstemious Wadding told the inquisitors how, with his Christian fellows, he had overpowered the Moorish crew members and taken the vessel to Lisbon. Treves' escape narrative was less dramatic. Re-sold in Salé, he was placed on a ship for Algiers which was intercepted by Spanish galleons at Sintra. Peter Hall's 1636 escape opportunity occurred during a corsair mission led by an English renegade. They were intercepted by Spanish forces, but, rather than regaining his liberty, the Irishman was imprisoned by the Spanish and set to row in their galleys. ${ }^{82}$

The consolidation of British naval power in the Western Mediterranean in the early eighteenth century permitted the development of a consular network

$81 \quad$ AHN INQ Lib 734, fols. $37 \mathrm{v}-38 \mathrm{v}$.

82 Ibidem, fols. $37 \mathrm{v}-38 \mathrm{v}$. 
in North Africa, helping to bring Irish hostages into sharper focus in British records and facilitating their ransoming as British subjects. ${ }^{83}$ Captain George Paddon was the first English envoy to Morocco after the treaty of Utrecht. He succeeded in negotiating a peace and friendship treaty in 1714, according to which all British residents of Gibraltar and Minorca were granted immunity from slavery. Nevertheless, contemporary accounts spoke of over four hundred English captured between 1714 and 1721, with nearly 300 of these in Meknes, including a number of renegades. ${ }^{84}$ In 1720 , the English counsel in Tetouan, Anthony Hatfield (1717-1728) reported that a woman, Margaret Shea, had been taken from the Welcome out of Cork, and had been forced to convert. ${ }^{85}$

She was not the only Irish subject who came to consular attention. In his diary of his mission to Morocco (July 1727-February 1728), Captain John Braithwaite (1696-1740) reported that an Irishman called Carr, a renegade of thirty years standing, acted as interpreter to the local ruler. ${ }^{86}$ Carr, apparently known as 'Alcaide Ally' or 'Believer' to the Moors, was an excellent example of trans-imperial mobility, successively adopting the Protestant, Catholic and Mohammedan faiths and associated political loyalties. ${ }^{87}$ During dinner with the English visitors, he claimed that his brother was a Royal Navy officer ${ }^{88}$ and he also alleged that he had served the English well, notably in the ransoming of Admiral George Delaval (c.1667-1723). ${ }^{89}$ Carr also ran the Moroccan sultan's foundry and oversaw the production of ordnance. In Meknes, the English counsel, George Russell reported a visit by a 'Mrs Shaw', an Irishwoman. ${ }^{90}$ This

83 Matar, British Captives 142. The cases of captive Catholics tended to be less well recorded. We know, for instance, of the 1719 capture of an Irish count's daughter only from French sources. Ibidem 130, citing Comelin F., de la Motte P. and Bernard J., Voyage pour la redemption des captifs, aux royaumes d'Alger et de Tunis, fait en 1720 (Paris, 1720) 26-42.

84 Anonymous, Description of the Nature of Slavery among the Moors (London, J. Peele: 1721) 13 .

85 Matar, British Captives 144 and 287, citing TNA SP 71/16/309. The other passengers were Daniel Healey, master, John Healey (d. 1721), Edmond Butler, Edmond Sheely, Dennis Birdan, Michael Gale and James Mahoney. See also Meunier D., Le consulat anglais à Tétouan sous Anthony Hatfield (1717-1728): étude et édition de textes (Tunis: 1980).

86 He also claimed to have been governor in Guinea and commander of the emperor's Jewish Guards. See Braithwaite, The History of the revolutions 180.

87 Pellow, T., The Adventures of Thomas Pellow of Penryn, Mariner (London: 189o) 32.

88 Ibidem 186.

89 Delaval had acted as English envoy to Morocco. In 1700 he negotiated the release of English captives and, in 1708, a British-Moroccan agreement not to molest each other's ships. See Byng G., Viscount Torrington - Byng J., The Byng papers: selected from the letters and papers of Admiral Sir George Byng, first Viscount Torrington, and of his son Admiral the Hon. John Byng, ed. B. Tunstall, vol. 2 (London: 1932) 270-273. Braithwaite, Revolutions 191. 
is probably the already mentioned Margaret 'Shea' as, according to Braithwaite, she had been captured by the Moors about nine years previously and forced to convert, at the insistence of the then sultan, Ismael Ibn Sharif. Having apparently tired of 'Mrs Shaw', he reportedly gifted her to a renegade Spanish soldier who allegedly reduced her to the unfortunate state in which Russell found her. If 'Mrs Shaw' was in fact, Margaret Shea, she was not among those ransomed with the surviving crew of the Welcome in $1734 .{ }^{91}$

\section{$4 \quad$ Conclusion}

The usually violent encounter between early modern Christendom and Islam, so vividly recorded in the experiences of Irish captives in the Western Mediterranean, is an intriguing instance of the triangular traffic between the English, Spanish and Moorish spheres. It is also an illustration of the increasingly unequal North-South confrontation between the European powers and their Moorish enemies. As European naval power, commercial clout and slaving enterprises grew, North Africa slowly shrank into relative economic and political subjection. This did not prevent, of course, corsair predations nor Islam's continued representation, in the European imagination, as a threat to both faith and dynasty. As Nabil Matar has pointed out, early modern English representations of Moorish captivity persistently communicated a stylized view of the historical experience that reveal more about changing geo-political realities, religious prejudice and personal advantage at home than about the lived cultural encounter in North Africa. ${ }^{92}$ The Spanish presentation of the Moor differs in detail but not in nature from its English contemporary. To say this is to take nothing, of course, from the hardships of enslavement in North Africa, so forcefully narrated in the surviving English, Portuguese and Spanish accounts. Nor is it to overlook Islam's allure, as a religion and as a way of life, for certain Christian renegades, especially the poorer and more socially marginalized..$^{93}$ It does, however, set that encounter within the larger context of the expanding European slaving enterprise within the emerging global economy, one that was

\footnotetext{
$91 \quad$ Matar, British Captives 291.

92 Matar N., "English Accounts of Captivity in North Africa and the Middle East, 1577-1625", Renaissance Quarterly 54, 2 (2001) 553-572. This also seems to have been the case with accounts drawn up by other European captives. See Gracián, J., Tratado de la redención de cautivos en que se cuentan las grandes miserias que padecen los cristianos que están en poder de infieles y cuán santa obra sea la de su rescate, ed. M.A. de Bunes Ibarra B. Alonso Acero (Sevilla: 2006).

93 Martínez Torres, Prisioneros de los infieles 120-127.
} 
comprehensively backed-up by naval and military might. Inevitably, European state and ecclesiastical records tend to present a partial view of the complexities of Moorish enslavement, one-sidedly Europhile and Islamophobe, with the Moors cast alternately as barbarically heathen or fecklessly exotic. ${ }^{94}$ It is, of course, possible to interpret the record more subversively. For instance, one could argue that the Christian fortitude so clearly on display, for instance, in Western accounts of Moorish captivity, is less evidence of any individual's religious integrity than a decoy from the attractions to Islam. One wonders, for example, if English, Scots or Irish indentured servants, on their way to servitude in the New World, would have thought themselves unfortunate if diverted, by corsair capture, to captivity in North Africa.

The specifically Irish dimension to the early modern encounter with Islam does little to modify this general assessment. The experience of Irish captives conforms to the general European model, though the specificities of their activities in both British and Spanish Mediterranean expansion owe something to their unusual politico-religious status. The fact that the majority of Irish captives were Catholics, for instance, lessened their chances of redemption by the British and Irish Protestant authorities. At the same time, thanks to the special status accorded them in Spain, Irish Catholics were eventually included in ransoming schemes supported by the monarquía. It can be argued that it was the civil disadvantaging of Irish Catholics under the Stuarts and Hanoverians, that drove them to act as agents of British expansion, especially in locations like the Tangier garrison, so unattractive to the London monarchy's more civilly protected subjects. Ironically, it was precisely the same set of disadvantages that channelled Irish subjects into Spanish networks, again in roles that the Madrid monarchy's better-placed subjects preferred to avoid.

\section{Bibliography}

\section{Primary Sources}

Anon., To his grace James duke of Ormonde, Lord Lieutenant General and General Governour of Ireland, the humble petition of Mercurius Lascary, a Grecian Priest (Dublin, s.n.: 1677).

Anon., Description of the Nature of slavery among the Moors (London, J. Peele: 1721).

94 For the other side of the story, see Matar N., Europe through Arab Eyes, 1578-1727 (New York: 2008). 
Archivo General de Simancas (= AGS)

Estado Leg $275^{2}$.

GA Legs 883, 954, 1399, 2866

GM Leg 1531, 2592

Hacienda Leg 966

Archivo Histórico Nacional, Madrid (= AHN)

Inquisición, Libs 734, 1021

Santiago Leg 5974

Archivo Monasterio de las Descalzas Reales

Archivio Storico di Propaganda Fide (= APF)

SOCG, 103, 140, 402

Arquivo Nacional do Torre do Tombo, Lisbon (= ANTT)

Tribunal do Santo Oficio (= TSO)

IC O25/O6752; IL O28/O110o; IL O28/O4891; IL O28/13113; IL O28/12428; IL O28/O5626; IL $028 / 4675$.

Braithwaite John, The History of the Revolutions in the Empire of Morocco upon the Death of the Late Emperor Muley Ishmael [...] (London: J. Darby - T. Browne, 1729).

Byng G., Viscount Torrington - Byng J., The Byng Papers: Selected from the Letters and Papers of Admiral Sir George Byng, First Viscount Torrington, and of his Son Admiral the Hon. John Byng, ed. B. Tunstall, 3 vols. (London: 1931-1932).

Gracián Jerónimo, Tratado de la redención de cautivos en que se cuentan las grandes miserias que padecen los cristianos que están en poder de infieles y cuán santa obra sea la de su rescate, ed. M.A. de Bunes Ibarra - B. Alonso Acero (Sevilla: 2006).

O'Heyne John, The Irish Dominicans of the Seventeenth Century (Louvain: 1706; reprint Dundalk: 1902).

[Philips George], The present state of Tangier: in a letter to his Grace the Lord Chancellor of Ireland and one of the Lords Justices there to which is added The Present State of Algiers (London: Henry Herringman, 1676).

Pierre, Dan, Histoire de la Barbarie et de ses Corsaires (Paris, Pierre Rocolet: 1637).

\section{Secondary Sources}

Alonso Acero B., Orán-Mazalquivir 1589-1639: una sociedad española en la frontera de Berbería (Madrid: 2000).

Barnby H., "The Sack of Baltimore", Journal of the Cork Historical and Archaeological Society 74 (1969) 101-129.

Barrio Gozalo M., "Los cautivos españoles en Argel durante el siglo ilustrado", Cuadernos Dieciochistas 2 (2003) 135-174.

Bejjit K., English Colonial Texts on Tangier 1661-1684: Imperialism and the Politics of Resistance (London: 2015). 
Bennassar B., Les chrétiens d'Allah. L'histoire extraordinaire des renégats XVI-XVII siècles (Paris: 1989).

Carabelli R., "The 'Oldest Modern' Colonisation in Africa”, in Nunes Silva C. (ed.), Urban Planning in North Africa (London: 2016) 31-42.

Chambers A., The Life and Times of Grace O'Malley (Dublin: 1979).

Chambers L., "The Irish in Europe in the Eighteenth Century 1691-1815", in Kelly J. (ed.),

The Cambridge History of Ireland, vol. 3: 1730-1880 (Cambridge: 2018) 569-592.

Childs J., The Army of Charles II (London: 2013).

Childs J., General Percy Kirke and the later Stuart army (London: 2014).

Colley L., Captives: Britain, Empire and the World 1600-1850 (London: 2002).

Davis R.C., Christian Slaves, Muslim Masters: White Slavery in the Mediterranean, the Barbary Coast and Italy (1500-1800) (London: 2003).

Downey D., "Beneath the Harp and Burgundian Cross: Irish Regiments in the Spanish Bourbon Army, 1700-1818", Revista internacional de historia militar 92 (2014) 83-105.

Druett J., She Captains: Heroines and Hellions of the Sea (New York: 200o).

Fé Cantó L.F., "El desembarco en Orán en 1732. Aproximación analítica a una operación compleja”, Revista Universitaria de Historia Militar 5, 10 (2016) 89-110.

Fenning H., "Irish Material in the Registers of the Dominican Masters General: 13901649", Archivum Fratrum Praedicatorum 39 (1969) 249-336.

Fenning H., "Irish Dominicans at Lisbon before 1700: A Biographical Register", Collectanea Hibernica 42 (2000) 27-65.

Filesi T., "Lattenzione della Sacra Congregazione per l'Africa settentrional", in Metzler J. (ed.), Sacrae Congregationis de Propaganda Fide memoria rerum: 350 anni al servizio delle missioni, 1622-1972, vol. 1, part 2 (Rome: 1972) 381-393.

Flynn T.S., The Irish Dominicans 1536-1641 (Dublin: 1993).

Friedman E.G., "North African Piracy on the Coast of Spain in the Seventeenth Century: A New Perspective on the Expulsion of the Moriscos", The International History Review 1, 1 (1979) 1-16.

García Hernán E., La cuestión irlandesa en la política internacional de Felipe II (Ph.D. dissertation: Universidad Complutense: 1999).

Gaughan J.A., "The Prince's Throne”, The Irish Monthly 44, 514 (1916) 235-241.

Giblin C., "Documents of the Irish Trinitarians, 1621-71", Collactanea Hibernica, 27/28 (1986) 11-43.

Guimerá Ravina A., "Historia de una incompetencia: el desembarco de Argel, 1775", Revista Universitaria de Historia Militar 5, 10 (2015) 135-155.

Guimerá Ravina A., Burguesía extranjera y comercio atlántico: la empresa comercial irlandesa en Canarias (1703-71) (Tenerife: 1985).

Heers J., Les Barbaresques (Paris: 2008).

Kerney Walsh M., "The Irish College Madrid", Seanchas Ardmhacha: Journal of the Armagh Diocesan Historical Society, 15, 2 (1993) 39-50. 
MacLean G. - Matar N., Britain and the Islamic World 1558-1713 (Oxford: 2011).

Martínez Torres A.J., Prisioneros de los infieles: vida y rescate de los cautivos cristianos en el Mediterráneo musulmán (siglos XVI-XVII) (Barcelona: 2004).

Matar N., Europe through Arab Eyes, 1578-1727 (New York: 2008).

Matar N., British Captives from the Mediterranean to the Atlantic, 1563-1760 (Leiden: 2014).

Matar N., Islam in Britain 1558-1685 (Cambridge: 1998).

Matar N., "English Accounts of Captivity in North Africa and the Middle East, 15771625", Renaissance Quarterly 54, 2 (2001) 553-572.

Meehan C.P., The Rise and Fall of the Irish Franciscan Monasteries [...], 5th ed. (Dublin: 1877).

Mesa E. de, The Irish in the Spanish Armies in the Seventeenth Century (Woodbridge: 2014).

Meunier D., Le consulat anglais à Tétouan sous Anthony Hatfield (1717-1728): étude et edition de textes (Tunis: 1980).

Moody T.W. et al. (eds.), A New History of Ireland, vol. 3: Early Modern Ireland 1534-1691 (Oxford: 1976).

Mous L., Estudio del manuscrito árabe de MustafáIbn Abd Allāh al Dahāwi sobre la liberación de Orán en el siglo XVIII (Ph.D. dissertation: University of Oran, 2013).

Murphy D., The Irish Brigades 1685-2006 (Dublin: 2007).

Murray T.D., "From Baltimore to Barbary: the ${ }_{1631}$ Sack of Baltimore", History Ireland 14, $4(2006) 14-18$.

O'Connor T., Irish Voices from the Spanish Inquisition: Migrants, Converts and Brokers in Early Modern Iberia (London: 2016).

O'Connor T., "Irish Collegians in Spanish Service (1560-180o)", in Chambers L. O'Connor T. (eds.), Forming Catholic Communities. Irish, Scots and English College Networks in Europe, 1569-1918 (Leiden: 2017) 15-38.

O'Reilly W., "Ireland in the Atlantic World: Migration and Cultural Transfer", in Ohlmeyer J. (ed.), The Cambridge History of Ireland: vol. 2: 1550-1730 (Cambridge: 2018) 385-408.

O'Scea C., Surviving Kinsale: Irish Emigration and Identity Formation in Early Modern Spain, 1601-40 (Manchester: 2015).

Panzac D., Les Corsaires barbaresques: la fin d'une épopée, 1800-1820 (Paris: 1999).

Recio Morales Ó., "Una aproximación al modelo del oficial extranjero en el ejército borbónico: la etapa de formación del teniente General Alejandro O’Reilly (17231794)", Cuadernos dieciochistas 12 (2011) 171-195.

Routh E.M.G., Tangier: England's Lost Atlantic Outpost 1661-1684 (London: 1912).

Stradling R.A., The Spanish Monarchy and Irish Mercenaries (Dublin: 1994).

White-Spunner B., Horse Guards (London: 2006). 